\title{
Effect of the air hammer on the hands of stonecutters. The limestone quarries of Bedford, Indiana, revisited
}

\author{
W TAYLOR, ${ }^{1}$ D WASSERMAN, ${ }^{2}$ V BEHRENS, ${ }^{2}$ D REYNOLDS, ${ }^{3}$ AND S SAMUELOFF \\ From the Department of Community and Occupational Medicine, ${ }^{1}$ University of Dundee, Scotland, and US \\ Department of Health and Human Services, ${ }^{2}$ National Institute for Occupational Safety and Health, Division \\ of Biomedical and Behavioral Science, Cincinnati, Ohio, Pelton-Blum Inc, ${ }^{3}$ Dallas, Texas, USA, and Hebrew \\ University, ${ }^{4}$ Hadassah Medical School, Jerusalem, Israel
}

ABSTRACT In the limestone quarries of Indiana, USA, pneumatic percussive hammers replaced the mallet and hammer around 1900. By 1917 the air hammer was being used exclusively for periods of eight to ten hours a shift. In 1918 Alice Hamilton investigated an unusual "disease" in these stonecutters of Bedford, Indiana, who complained of "attacks of numbness and blanching of the fingers coming on suddenly under the influence of cold and then disappearing." The prevalence of vibration induced white finger (VWF) found in this population of 38 stonecutters was $89 \%$, with decreased light touch, pain, and temperature appreciation in advanced cases. In 1978 a VWF research team revisited these limestone quarries. During the 60 year interval the stonecutting industry had contracted from 4000 workers in 40 quarries in 1918 to 3-400 in 10 quarries in 1978, with only 50 employees remaining in the Bedford area. In a population of 30 stonecutters the prevalence of VWF in 1978 was $80 \%$, with similar sensory loss in light touch, pain, and temperature appreciation. Between 1918 and 1978 no change had taken place in the design of the air hammers used for stonecutting. Vibration levels of 4859 metres $/ \mathrm{s}^{2}$ on the chisel, and 2010 metres $/ \mathrm{s}^{2}$ on the barrel were measured over a frequency range $6 \cdot 3$ to $1000 \mathrm{~Hz}$. The fundamental frequency was $75 \mathrm{~Hz}$. These measured vibration levels are outside the ISO/DIS/ 5349 (1979) rcommended limits for human exposure to vibration transmitted to the hand. The VWF data presented in this paper, and those originally reported by Hamilton in 1918, call for an immediate redesign of stonecutting pneumatic hammers in order to remove one cause of Raynaud's phenomenon of occupational origin.

\section{"A disproportionate amount of time and talent has been expended upon the study of 'dead fingers,' a relatively harmless occupational disease." \\ R Meeker, US Commissioner of Labor Statistics (1918).}

Air hammers were first introduced for carving and stonecutting in the oolitic limestone belt of Indiana around 1895 , supplanting the traditional mallet and hammer in the quarries of Stinesville, Elletsville, Bloomington, and Bedford. By 1910 the use of the air hammer in some quarries had reached eight to ten hours a shift and by 1917 the mallet and hammer had been discarded everywhere. The limestone industry consisted then of some 4000 employees in 40 mills and quarries and many of the fine buildings in Washington and New York were built with this white Indiana limestone.
In 1918 Alice Hamilton investigated an unusual disease in stonecutters from the Indiana region where complaints had arisen of "attacks of numbness and blanching in the fingers, particularly of the chisel hand, coming on suddenly under the influence of cold, and then disappearing."' She reported, "... the trouble I found among the limestone cutters is a spastic anemia affecting the arterioles of the fingers and hands. It comes on in sudden and recurring attacks under the stimulus of cold as does Raynaud's syncope. It is not symmetrical even when in both hands and does not result in wasting and death of tissue which accompany Raynaud's. I did not see any marked swelling or excessive congestion or severe pain. Nor did I see hands with thickened fingers or deformed nails; on the contrary these stonecutters had well formed and well preserved nails such as one seldom sees in manual workers. No history was given me of necrosis or blisters or ulcers 
or desquamating skin. The left hand is usually the one affected and when the right hand suffers the fingers involved are not the ones corresponding to those involved on the left hand." This classic description of Raynaud's phenomenon of occupational origin (or vibration induced white finger designated hereafter as VWF) was made after Hamilton's first visit to Bedford and Bloomington in April 1917. It is of interest to note that all the investigating physicians of this period, including those from the Bureau of Labor Statistics, the Public Health Service, and the United States Army were in agreement that the "disease" was occupational in origin and was due to the use of the air hammer. Arising from a second visit to Indiana in January 1918 Hamilton referred eight stonecutters to Rothstein, ${ }^{2}$ professor of nervous and mental diseases at the Presbyterian Hospital in Chicago, with the object of further investigations into the sensory areas of light touch, pain, and temperature. In her field surveys in Indiana she had found definite impairment of sensation in the digits, inability to do fine work, and a general clumsiness in manual tasks in addition to the blanching of the digits.

From the comprehensive data reported in the Bureau of Labor Statistics report it is possible to stage assess Rothstein's eight stonecutters (Table 1).

The mean age of this group was $32(24-45)$, the mean vibration exposure 9.4 years $(3.5-18)$, and the latent period 1.9 years $(1.5-2.5)$ for five subjects, the remaining three subjects being unable to remember with certainty the onset of white finger. The daily air hammer usage was seven hours. If the 1978 method of assessment ${ }^{3}$ is now used there were in this series five stage 3 , two stage 2 , and one $0_{N}$. None of the eight cases admitted any decrease in grip force or muscle weakness. Three other clinical observations were reported (a) absence of hair on the dorsum of the hands ( 4 cases), (b) mechanical stimuli (pin prick or blunt objects or both) caused an abnormal vasomotor constriction, and (c) decreased touch sensation in the digits which often extended into the forearms. Finally, it should be noted that the entire clinical testing procedures were done on warm hands and never during, or immediately after, a blanching attack.

In the Indiana limestone belt Hamilton surveyed 38 stonecutters from the towns of Bedford and Bloomington. She reported "... among the 38 limestone cutters and carvers there were only four who had never had white fingers," a prevalence of VWF of $89.5 \%$. From her Bedford survey she gives us a latent interval of 1.2 to 1.5 years. We are told that the left hand (chisel) is most affected and that stonecutters have difficulty reading newspapers and "must therefore continually put the hands down to coax the blood back into the hands." She discovered that stonecutters have a loss of sensation in the fingers and that their sleep pattern is disturbed because of numb digits. Her survey also showed that some isolated patients could use the air hammer six to seven hours a day for up to 23 years without complaints of blanching attacks.

Finally, she summarised the disease thus: “. . . the condition (blanching) does not impair the skill in the fingers for ordinary interior stonecutting and carving, but makes it impossible for a man to do outside cutting in cold weather or to take up a skilled trade in which the hands are exposed to cold."

\section{Bedford revisited: 1978}

During 1978 the National Institute of Occupational Health and Safety (NIOSH), Cincinnati, conducted vibration white finger surveys in the United States in two foundries and one shipyard, vibration medical data being collected on 385 volunteer workers exposed to vibration when using hand held pneumatic tools for the chipping and grinding of surplus metal from castings. The data have been reported by Wasserman in two volumes. ${ }^{45}$ Before disbanding the vibration team it was decided to visit the limestone

Table 1 Summary of clinical findings on eight stonecutters examined by Rothstein (1918)

\begin{tabular}{|c|c|c|c|c|c|c|c|c|c|c|c|c|c|c|c|c|c|}
\hline \multirow{3}{*}{$\begin{array}{l}\text { Case } \\
\text { No }\end{array}$} & \multirow{3}{*}{$\begin{array}{l}\text { Age } \\
\text { (years) }\end{array}$} & \multirow{3}{*}{$\begin{array}{l}\text { Vibration } \\
\text { exposure } \\
\text { (years) }\end{array}$} & \multirow{3}{*}{$\begin{array}{l}\text { Latent } \\
\text { period } \\
\text { (years) }\end{array}$} & \multirow[t]{3}{*}{ Stage } & \multicolumn{3}{|c|}{ Sensory tests } & \multicolumn{10}{|c|}{ Finger blanching } \\
\hline & & & & & \multirow[t]{2}{*}{ Touch } & \multirow[t]{2}{*}{ Pain } & \multirow[t]{2}{*}{ Temp } & \multicolumn{5}{|c|}{ Left hand } & \multicolumn{5}{|c|}{ Right hand } \\
\hline & & & & & & & & $T$ & 1 & 2 & 3 & 4 & $T$ & 1 & 2 & 3 & 4 \\
\hline $\begin{array}{l}1 \\
2 \\
3 \\
4 \\
5 \\
6 \\
7 \\
8\end{array}$ & $\begin{array}{l}40 \\
26 \\
45 \\
28 \\
24 \\
38 \\
24 \\
33\end{array}$ & $\begin{array}{c}7 \\
3^{1 / 2} \\
12 \\
7 \\
8 \\
11^{1 / 2} \\
8 \\
18\end{array}$ & $\begin{array}{l}- \\
- \\
11 / 2 \\
21 / 2 \\
2 \\
1 \cdot 5 \\
2 \\
-\end{array}$ & $\begin{array}{l}3 \\
2 \\
3 \\
3 \\
3 \\
3 \\
2 \\
0_{N}\end{array}$ & $\begin{array}{l}\# \\
\# \\
\# \\
\# \\
\# \\
\# \\
\# \\
-\end{array}$ & $\begin{array}{l}\# \\
\# \\
\# \\
\# \\
\# \\
- \\
-\end{array}$ & $\begin{array}{l}\# \\
\# \\
\# \\
\# \\
\# \\
\# \\
- \\
-\end{array}$ & $\begin{array}{l}+ \\
0 \\
+ \\
+ \\
+ \\
+ \\
0 \\
0\end{array}$ & $\begin{array}{l}+ \\
+ \\
+ \\
+ \\
+ \\
+ \\
+ \\
0\end{array}$ & $\begin{array}{l}+ \\
+ \\
+ \\
+ \\
+ \\
+ \\
+ \\
0\end{array}$ & $\begin{array}{l}+ \\
+ \\
+ \\
+ \\
+ \\
+ \\
+ \\
0\end{array}$ & $\begin{array}{l}+ \\
+ \\
+ \\
+ \\
+ \\
+ \\
+ \\
0\end{array}$ & $\begin{array}{l}+ \\
0 \\
+ \\
+ \\
+ \\
+ \\
0 \\
0\end{array}$ & $\begin{array}{l}+ \\
0 \\
+ \\
+ \\
+ \\
+ \\
+ \\
0\end{array}$ & $\begin{array}{l}+ \\
0 \\
+ \\
0 \\
+ \\
+ \\
+ \\
0\end{array}$ & $\begin{array}{l}+ \\
0 \\
+ \\
0 \\
+ \\
+ \\
0 \\
0\end{array}$ & $\begin{array}{l}0 \\
0 \\
+ \\
0 \\
0 \\
+ \\
0 \\
0\end{array}$ \\
\hline
\end{tabular}

\# = Decreased sensation.

$+=$ White or blanched finger.

$-=$ Normal sensation.

$0=$ Normal. 
quarries of Indiana (Bedford) in August 1978. During the 60 year interval since the original Hamilton-Rothstein surveys the industry has contracted from 4000 workers in 40 quarries and mills to 3-400 in 10 quarries and mills. Within the Bedford area only 50 employees remained. Realising that it would not be possible to establish a dose effect relationship from this small sample, only 30 subjects were examined, for historical reasons, using the same medical clinical and objective diagnostic procedures as those adopted for the main study.

\section{Types of hand held pneumatic tools}

In the Bedford limestone industry there are two distinct activities, stone drilling and stonecutting/ carving. The driller uses a large pneumatic drill in which the bit rotates as well as impacts (fig 1). This tool resembles a road or pavement breaker, is 25 inches long and weighs about 30 pounds. The operator places both hands on a " $T$ ' bar handle and consequently there is no direct hand contact with either the barrel or the chisel. Stone drilling is confined to the quarry where holes are drilled two

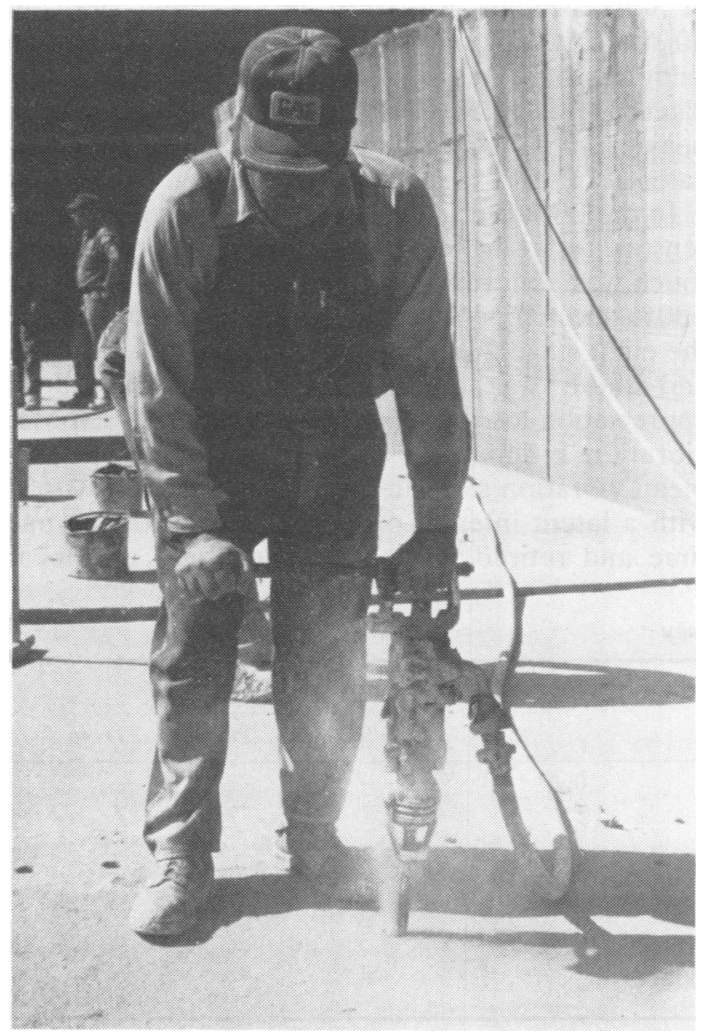

Fig 1 Stone drilling in Bedford limestone quarry. feet apart into which wedges are driven thus enabling large slabs of limestone to be removed from the work face. The average drilling vibration exposure time is three hours a day. The carver's task, by contrast, is that of a skilled artisan using a light weight air driven chipping hammer with chisel inserts of varying lengths and shapes, carving and cutting the fine relief sculpturing found on many public buildings and tombstones. The carver holds his hammer in a similar way to foundry chippers. One hand, usually the left (in right handed subjects), tightly encircles the chisel and guides the tool on the workpiece. The other hand holds the body of the chipping hammer and controls the impacts of the hammer with the thumb placed on the air exhaust valve. This type of chipping tool is one foot long and weighs three to four pounds. It operates at about 4500$4600 \mathrm{rpm}$ (corresponding to $75-77 \mathrm{~Hz}$ ) dependent on the operating air pressure, normally around 80-90 psi.

\section{Vibration data}

The methods used for acquiring the vibration acceleration data, and the subsequent analyses, have been detailed in the NIOSH study of foundry chippers and grinders. ${ }^{5}$ Measurements were made on the Bedford stone chipping air hammers and recordings made of a one minute continuous run with two $B$ and $\mathrm{K}$ Model 8309 accelerometers mounted on the barrel. The accelerometer outputs were routed to two amplifiers (Ithaco Model 461) and to a multichannel FM tape recorder (Honeywell Model 5600-C) for data storage. To guarantee charge amplifier signal integrity (no DC shifting, no amplifier overloading etc) a multichannel monitoring oscilliscope (Tektronix Model 5103) was used. Simultaneously, preliminary Fourier spectrum analysis was obtained on-line during data acquisition using a Nicolet Model 444A FFT portable computer.

During slot limestone chipping with the tool operated at full throttle at $90 \mathrm{psi}$ air pressure the acceleration (axial axis) measured at the chisel was 4859 metres/ $/ \mathrm{s}^{2}$ (or $494 \mathrm{~g}$ 's-rms). On the barrel (handle of the tool) the acceleration measured was 2010 metres/ $\mathrm{s}^{2}$ (205 g's $\mathrm{rms}$ ). These acceleration levels were obtained over the frequency range 6.3 to $1000 \mathrm{~Hz}$. The fundamental frequency was $75 \mathrm{~Hz}$ with harmonics at 150,225 to $250 \mathrm{~Hz}$. The corresponding energy directed into the hand was calculated to be $4140 \mathrm{Joules} / \mathrm{s}$ on the chisel and 1990 Joules/s on the barrel (handle). For this small limestone chipper, where the principal frequency is around 75 to $80 \mathrm{~Hz}, 88 \%$ of the energy was found at this frequency and below. The NIOSH survey of 
chipping hammers and grinders, including the small stone chipper used at Bedford, indicated that substantially more energy is transmitted to the handarm system from the handles of small chipping hammers than from the handles of large chipping hammers. ${ }^{5}$ In no case did the chipping hammer chisel acceleration measurements fall within an acceptable time corrected ISO exposure limit. ${ }^{\circ}$

\section{Bedford population}

From the total available population of 50 limestone workers in the Bedford area, 30 subjects volunteered for VWF examination (60\% response rate). In a trade in severe recession this volunteer population has a skewed age distribution in that of the $\mathbf{3 0}$ subjects surveyed, two were over 75 , nine between 70 and 74 , and 17 were 50 and over (table 2).

Since there are many other secondary causes of white finger including primary Raynaud's disease, crush injuries of the hands and fingers (lacerations, fractures), and medical conditions, 10 of the 30 subjects were rejected for the reasons shown in table 3 , thus leaving 20 "pure" vibration exposed subjects for analyses. Of these 20 , seven were currently exposed to vibration, eight were part time and retired stonecutters, and five were quarry drillers.

\section{Method}

The methodology and testing techniques used at Bedford were those used in the vibration white

Table 2 Age distribution of 30 Bedford stonecutters and drillers (1978 sürvey)

\begin{tabular}{cccccccc}
\hline $20-24$ & $25-29$ & $30-34$ & $35-39$ & $40-49$ & $50-60$ & $60-70$ & $70-79^{*}$ \\
\hline 1 & 1 & 2 & 3 & 6 & 5 & 1 & 11 \\
\hline
\end{tabular}

*Thirty seven per cent of survey subjects aged 70 and over. finger surveys of foundry and chippers. ${ }^{4}$ Two mobile road trailers were used, the first housing the medical team (interviewer, 2 doctors, $x$ ray, objective tests) and the second the vibration measuring equipment. The first doctor carried out a general medical examination of blood pressure, heart, and hands with special reference to trauma, lacerations, fractures, and callus formation. The second doctor measured the skin temperature of the digits and, if normal, carried out sensory tests-light touch, pain, and temperature appreciation. The vibration measurements were made at the same time as the medical examinations. The stage assessments, indicating the severity of VWF, were made according to the scheme devised by Taylor and Pelmear. ${ }^{3}$

\section{Results}

The clinical data obtained for the three population groups, active stonecutters/carvers, retired and part time stonecutters/carvers, and drillers are shown in tables 4,5 , and 6 .

The prevalence of white finger in the $\mathbf{3 0}$ subjects, defined as the percentage of subjects with stage 1,2 , or 3 assessments, was $63 \%$, representing 19 of the 30 subjects. Taking only the 15 stonecutter/carvers using the light 3-4 pounds hammer, the VWF prevalence was $80 \%$. The quarry drillers using the heavier 30 pound air hammer/drill had a VWF prevalence of $20 \%$ (see table 7 ).

In the 20 subjects chosen for analyses the routine sensory tests showed that in the four stage 3 cases touch was abnormal in $75 \%$, and there was pain in $100 \%$ and temperature appreciation loss in $75 \%$. In the eight stage 2 cases touch was abnormal in $62 \%$, and there was pain in $50 \%$ and temperature appreciation loss in $50 \%$. For the currently exposed vibration group of seven stonecutters/carvers the mean vibration exposure time was 28 years $(9-60)$, with a latent interval of 4.6 years and for the part time and retired group of stonecutters, the mean

Table 3 Reasons for rejection of 10 subjects from Bedford survey

\begin{tabular}{|c|c|c|c|c|c|}
\hline \multirow[t]{2}{*}{ Job title } & \multirow[t]{2}{*}{ Reason for rejection } & \multirow[t]{2}{*}{ Stage assessment } & \multicolumn{3}{|c|}{ Sensory tests } \\
\hline & & & Touch & Pain & Temp \\
\hline $\begin{array}{l}\text { Maintenance } \\
\text { Driller } \\
\text { Engineer } \\
\text { Instructor } \\
\text { Stonecutter } \\
\text { Mechanic } \\
\text { Stonecutter } \\
\text { Stonecutter } \\
\text { Stonecutter } \\
\text { Stonecutter }\end{array}$ & $\begin{array}{l}\text { Ex-driller }\left(\begin{array}{ll}18 & y\end{array}\right) \text { now engineer } \\
\text { Ex-driller }(20 \text { y) hypertension } \\
\text { Ex-driller }(20 \text { y) maintenance } \\
\text { Ex-driller }(11 \text { y) road ripper } \\
\text { Primary Raynaud's disease } \\
\text { Mixed vibration ( } 26 \text { y) chain saws } \\
\text { Vibration exposure ( } 34 \text { y) (surgery) } \\
\text { Vibration exposure ( } 30 \text { y) crush injury } \\
\text { Ex-vibration } 13 \text { y intermittent } \\
\text { Frostbite ( } R \text { and L hands) }\end{array}$ & $\begin{array}{l}{ }_{2} \mathrm{NT} \\
0 \\
0 \\
0_{\mathrm{T}}^{\mathrm{T}} \\
3 \\
3 \\
2 \\
2 \\
1\end{array}$ & $\begin{array}{l}\overline{+} \\
- \\
- \\
\overline{+} \\
+ \\
\overline{+} \\
+\end{array}$ & $\begin{array}{l}\overline{+} \\
- \\
- \\
\overline{+} \\
+ \\
\overline{+} \\
-\end{array}$ & $\begin{array}{l}+ \\
+ \\
- \\
- \\
+ \\
+ \\
+ \\
+\end{array}$ \\
\hline
\end{tabular}

- Normal sensation.

+ Abnormal (reduced sensation). 
Table 4 Clinical data for seven current stonecutters/carvers

\begin{tabular}{|c|c|c|c|c|c|c|c|c|c|c|c|c|c|c|c|c|c|}
\hline \multirow{3}{*}{$\begin{array}{l}\text { Case } \\
\text { No }\end{array}$} & \multirow{3}{*}{$\begin{array}{l}\text { Age } \\
\text { (years) }\end{array}$} & \multirow{3}{*}{$\begin{array}{l}\text { Vibration } \\
\text { exposure } \\
\text { (years) }\end{array}$} & \multirow{3}{*}{$\begin{array}{l}\text { Latent } \\
\text { period } \\
\text { (years) }\end{array}$} & \multirow[t]{3}{*}{ Stage } & \multicolumn{3}{|c|}{ Sensory tests } & \multicolumn{10}{|c|}{ Finger blanching } \\
\hline & & & & & \multirow[t]{2}{*}{ Touch } & \multirow[t]{2}{*}{ Pain } & \multirow[t]{2}{*}{ Temp } & \multicolumn{5}{|c|}{ Left hand } & \multicolumn{5}{|c|}{ Right hand } \\
\hline & & & & & & & & $T$ & 1 & 2 & 3 & 4 & $T$ & 1 & 2 & 3 & 4 \\
\hline $\begin{array}{l}1 \\
2 \\
3 \\
4 \\
5 \\
6 \\
7\end{array}$ & $\begin{array}{l}76 \\
48 \\
73 \\
34 \\
27 \\
49 \\
32\end{array}$ & $\begin{array}{r}60 \\
28 \\
48 \\
12 \\
9 \\
30 \\
9\end{array}$ & $\begin{array}{r}- \\
5 \\
-5 \\
10 \\
1\end{array}$ & $\begin{array}{l}0 \mathrm{~T} \\
3 \\
2 \\
0 \mathrm{~T} \\
2 \\
2 \\
1\end{array}$ & $\begin{array}{l}- \\
\overline{-} \\
\overline{+} \\
+ \\
-\end{array}$ & $\begin{array}{l}\overline{+} \\
- \\
\overline{+} \\
+ \\
+\end{array}$ & $\begin{array}{l}- \\
+ \\
- \\
+ \\
+ \\
+\end{array}$ & $\begin{array}{l}0 \\
0 \\
0 \\
0 \\
0 \\
0 \\
+\end{array}$ & $\begin{array}{l}0 \\
+ \\
+ \\
0 \\
0 \\
+ \\
+\end{array}$ & $\begin{array}{l}0 \\
+ \\
+ \\
0 \\
+ \\
+ \\
0\end{array}$ & $\begin{array}{l}0 \\
+ \\
+ \\
0 \\
+ \\
+ \\
0\end{array}$ & $\begin{array}{l}0 \\
+ \\
+ \\
0 \\
+ \\
+ \\
0\end{array}$ & $\begin{array}{l}0 \\
+ \\
+ \\
0 \\
0 \\
0 \\
+\end{array}$ & $\begin{array}{l}0 \\
+ \\
+ \\
0 \\
0 \\
0 \\
0\end{array}$ & $\begin{array}{l}0 \\
+ \\
+ \\
0 \\
0 \\
0 \\
0\end{array}$ & $\begin{array}{l}0 \\
+ \\
+ \\
0 \\
0 \\
0 \\
+\end{array}$ & $\begin{array}{l}0 \\
+ \\
+ \\
0 \\
0 \\
0 \\
0\end{array}$ \\
\hline
\end{tabular}

$0=$ Normal. $\quad+=$ White or blanched finger.

Table 5 Clinical data for eight part time and retired stonecutters/carvers

\begin{tabular}{|c|c|c|c|c|c|c|c|c|c|c|c|c|c|c|c|c|c|c|}
\hline \multirow{3}{*}{$\begin{array}{l}\text { Case } \\
\text { No }\end{array}$} & \multirow{3}{*}{$\begin{array}{l}\text { Age } \\
\text { (years) }\end{array}$} & \multirow{3}{*}{$\begin{array}{l}\text { Vibration } \\
\text { exposure } \\
\text { (years) }\end{array}$} & \multirow{3}{*}{$\begin{array}{l}\text { Latent } \\
\text { period } \\
\text { (years) }\end{array}$} & \multirow{3}{*}{$\begin{array}{l}\text { Retired } \\
\text { interval } \\
\text { (years) }\end{array}$} & \multirow[t]{3}{*}{ Stage } & \multicolumn{3}{|c|}{ Sensory tests } & \multicolumn{10}{|c|}{ Finger blanching } \\
\hline & & & & & & \multirow[t]{2}{*}{ Touch } & \multirow[t]{2}{*}{ Pain } & \multirow[t]{2}{*}{ Temp } & \multicolumn{5}{|c|}{ Left hand } & \multicolumn{5}{|c|}{ Right hand } \\
\hline & & & & & & & & & $T$ & 1 & 2 & 3 & 4 & $T$ & 1 & 2 & 3 & 4 \\
\hline $\begin{array}{l}1 \\
2 \\
3 \\
4 \\
5 \\
6 \\
7 \\
8\end{array}$ & $\begin{array}{l}73 \\
74 \\
70 \\
74 \\
78 \\
72 \\
71 \\
72\end{array}$ & $\begin{array}{l}40 \\
49 \\
48 \\
50 \\
47 \\
42 \\
39 \\
47\end{array}$ & $\begin{array}{r}15 \\
10 \\
4 \\
\frac{-}{23} \\
\frac{2}{2}\end{array}$ & $\begin{array}{r}1 \\
3 \\
5 \\
10 \\
13 \\
8 \\
4 \\
9\end{array}$ & $\begin{array}{l}2 \\
3 \\
2 \\
2 \\
2 \\
2 \\
0 \\
3\end{array}$ & $\begin{array}{l}+ \\
- \\
+ \\
- \\
+ \\
+ \\
+\end{array}$ & $\begin{array}{l}\frac{+}{+} \\
\frac{+}{+} \\
+\end{array}$ & $\begin{array}{l}- \\
\overline{+} \\
\frac{+}{+} \\
+ \\
+\end{array}$ & $\begin{array}{l}0 \\
+ \\
0 \\
0 \\
0 \\
0 \\
0 \\
+\end{array}$ & $\begin{array}{l}0 \\
+ \\
+ \\
0 \\
0 \\
+ \\
0 \\
+\end{array}$ & $\begin{array}{l}+ \\
+ \\
+ \\
0 \\
0 \\
+ \\
0 \\
+\end{array}$ & $\begin{array}{l}+ \\
+ \\
+ \\
0 \\
0 \\
+ \\
0 \\
+\end{array}$ & $\begin{array}{l}0 \\
+ \\
+ \\
0 \\
0 \\
+ \\
0 \\
+\end{array}$ & $\begin{array}{l}0 \\
+ \\
0 \\
0 \\
0 \\
0 \\
0 \\
+\end{array}$ & $\begin{array}{l}0 \\
+ \\
0 \\
0 \\
0 \\
0 \\
0 \\
+\end{array}$ & $\begin{array}{l}+ \\
+ \\
0 \\
+ \\
+ \\
0 \\
0 \\
+\end{array}$ & $\begin{array}{l}+ \\
+ \\
0 \\
+ \\
+ \\
0 \\
0 \\
+\end{array}$ & $\begin{array}{l}0 \\
+ \\
0 \\
+ \\
+ \\
0 \\
0 \\
+\end{array}$ \\
\hline
\end{tabular}

$0=$ Normal. $\quad+=$ White or blanched finger.

Table 6 Clinical data for five limestone quarry drillers

\begin{tabular}{|c|c|c|c|c|c|c|c|c|c|c|c|c|c|c|c|c|c|}
\hline \multirow{3}{*}{$\begin{array}{l}\text { Case } \\
\text { No }\end{array}$} & \multirow{3}{*}{$\begin{array}{l}\text { Age } \\
\text { (years) }\end{array}$} & \multirow{3}{*}{$\begin{array}{l}\text { Vibration } \\
\text { exposure } \\
\text { (years) }\end{array}$} & \multirow{3}{*}{$\begin{array}{l}\text { Latent } \\
\text { period } \\
\text { (years) }\end{array}$} & \multirow[t]{3}{*}{ Stage } & \multicolumn{3}{|c|}{ Sensory tests } & \multicolumn{10}{|c|}{ Finger blanching } \\
\hline & & & & & \multirow[t]{2}{*}{ Touch } & \multirow[t]{2}{*}{ Pain } & \multirow[t]{2}{*}{ Temp } & \multicolumn{5}{|c|}{ Left hand } & \multicolumn{5}{|c|}{ Right hand } \\
\hline & & & & & & & & $T$ & 1 & 2 & 3 & 4 & $T$ & 1 & 2 & 3 & 4 \\
\hline $\begin{array}{l}1 \\
2 \\
3 \\
4 \\
5\end{array}$ & $\begin{array}{l}73 \\
48 \\
54 \\
54 \\
61\end{array}$ & $\begin{array}{r}32 \\
27 \\
2 \\
7 \\
33\end{array}$ & $\frac{-}{-}$ & $\begin{array}{l}0_{\mathrm{T}} \\
\mathrm{O}_{\mathrm{T}} \\
\mathrm{O}_{\mathrm{N}} \\
\mathrm{O}_{\mathrm{NT}} \\
3\end{array}$ & $\frac{+}{+} \frac{}{+}$ & $\begin{array}{l}+ \\
- \\
+ \\
+\end{array}$ & $\begin{array}{l}+ \\
+ \\
+ \\
+\end{array}$ & $\begin{array}{l}\mathbf{0} \\
\mathbf{0} \\
\mathbf{0} \\
\mathbf{0} \\
\mathbf{0}\end{array}$ & $\begin{array}{l}0 \\
0 \\
0 \\
0 \\
+\end{array}$ & $\begin{array}{l}0 \\
0 \\
0 \\
0 \\
+\end{array}$ & $\begin{array}{l}0 \\
0 \\
0 \\
0 \\
+\end{array}$ & $\begin{array}{l}0 \\
0 \\
0 \\
0 \\
+\end{array}$ & $\begin{array}{l}\mathbf{0} \\
0 \\
0 \\
0 \\
0 \\
0\end{array}$ & $\begin{array}{l}0 \\
0 \\
0 \\
0 \\
+\end{array}$ & $\begin{array}{l}0 \\
0 \\
0 \\
0 \\
+\end{array}$ & $\begin{array}{l}0 \\
0 \\
0 \\
0 \\
+\end{array}$ & $\begin{array}{l}0 \\
0 \\
0 \\
+\end{array}$ \\
\hline
\end{tabular}

$0=$ Normal. $\quad+=$ White or blanched finger.

Table 7 VWF prevalence in 30 Bedford stonecutters and drillers (1978)

\begin{tabular}{|c|c|c|c|c|c|c|c|c|c|}
\hline \multirow[t]{2}{*}{ No of subjects } & \multicolumn{9}{|c|}{ Stage assessment } \\
\hline & 0 & $\sigma_{N}$ & $O_{T}$ & $O_{N T}$ & Total & 1 & 2 & 3 & Total \\
\hline $\begin{array}{l}\text { Total sample }(n=30) \\
\text { Stonecutter/carvers }(n=15) \\
\text { Quarry drillers }(n=5)\end{array}$ & $\begin{array}{l}2 \\
1 \\
-\end{array}$ & $\frac{2}{1}$ & $\begin{array}{l}5 \\
2 \\
2\end{array}$ & $\frac{2}{1}$ & $\begin{array}{r}11 \\
3 \\
4\end{array}$ & $\underline{1}$ & $\begin{array}{r}13 \\
8 \\
-\end{array}$ & $\begin{array}{l}5 \\
3 \\
1\end{array}$ & $\begin{array}{r}19 \\
12 \\
1\end{array}$ \\
\hline
\end{tabular}

(a) VWF prevalence of total sample examined $(n=30)=63 \%$.

(b) VWF prevalence of stonecutter/carvers $(n=15)=80 \%$.

(c) VWF prevalence of drillers $(n=5)=20 \%$. 
vibration exposure was 45 years $(39-50)$ with a latent interval of 10 years $(2-23)$.

\section{Discussion}

After the two major VWF surveys of pneumatic tool operators in foundries in the United States in 1978, the decision to carry out a limited study on the stonecutters of Bedford, Indiana, was made for historical reasons. This population had last been surveyed 60 years ago at the request of $R$ Meeker, the US Commissioner of Labor Statistics, after the complaints arising from stonecutters using air hammers. The link with the present is that the air hammer design has remained stationary throughout the 60 year interval. Therefore it is permissible, because both the vibration stimulus and the rock strata remain the same, to compare the HamiltonRothstein data with the findings reported here, recognising the epidemiological and statistical limitations present in both surveys. The objection to the 1918 data is the limited number of subjects and that those which are so concisely and comprehensively documented in the 1918 US Bureau of Labor statistics report No 19 were to a large extent selected. The sample in the present study is similarly limited largely owing to the recession in the limestone industry and consisted of volunteers, but nevertheless the prevalence of VWF, in the present study $(80 \%)$, is similar to that found in the HamiltonRothstein study ( $89.5 \%)$. These figures indicate that the small light air hammer is an unsafe tool. The latent period (the time interval between stage 0 and stage 1) has always been regarded as a better indicator of risk than the prevalence rate. ' The Rothstein data from the detailed hospital records ${ }^{2}$ give a latent period of 1.9 years $(1.5-2.5)$ for five subjects. The present Bedford survey gives a latent period of 4.6 years for seven subjects. Possibly the longer daily vibration exposure time would account for the shorter latent period in the 1918 survey. Both figures may be taken only as a guide to the severity of the vibration hazard.

The present survey showed an unusual age distribution. This is illustrated in the part time, retired stonecutter group of eight subjects with a mean age of 73 (70-78) and a mean vibration exposure time of 45 years (39-50). Such stability of employment is uncommon in present day industrial populations. In this group of eight subjects were five stage 2 and two stage 3 , illustrating the irreversibility of VWF in a group with retirement vibration free intervals of from four to 13 years (mean 6.6 years). On the other hand, as in noise induced deafness, where some subjects never show a response to the noise stimulus, two subjects illustrate this biological variation. In

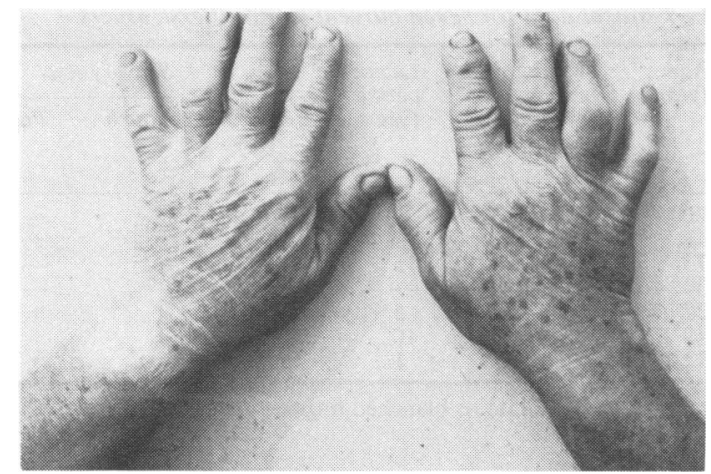

Fig 2 Hands of a 76 year old stone cutter that have been exposed to vibration for 60 years with no complaints other than tingling of the hands at night.

the retired group a stonecutter aged 71 had had 39 years continuous use of the air hammer and no complaints. In the current active group a stonecutter aged 76 had 60 years of continuous air hammer vibration exposure and had no complaints other than tingling of the hands at night (fig 2).

Subjects using the hammer/drill in the quarries were not studied in depth by the HamiltonRothstein team. In the present survey a limited number (five subjects) were examined, mean age 58 (48-73), mean vibration exposure time 20 years (2-33), with one stage $0_{\mathrm{N}}$, two stage $0_{\mathrm{T}}$, one stage $0_{\mathrm{NT}}$, and one stage 3 . The limited evidence obtained suggests that the heavier hammer/drill is less hazardous than the lighter air hammer used by the stonecutters.

With reference to the clinical tests for sensory function it is of interest to analyse the 1918 Hamilton-Rothstein data (table 1) with particular emphasis on the five stage 3 cases. The percentage abnormality (impairment or decreased sensitivity) for each test was light touch $80 \%$, pain $80 \%$, and loss of temperature appreciation $100 \%$. In the 1978 survey were four stage 3 cases giving abnormalities in light touch of $75 \%$, in pain of $100 \%$, and in temperature appreciation of $75 \%$. For eight stage 2 cases the losses were, light touch $62 \%$, pain $50 \%$, and temperature appreciation $50 \%$ and for the seven in stages $0,0_{\mathrm{N}}, 0_{\mathrm{T}}$, and $0_{\mathrm{NT}}$ the percentage abnormalities were light touch $43 \%$, pain $29 \%$, and temperature appreciation $57 \%$. In control populations tested in the 1978 foundry VWF surveys the percentage abnormality for these non-vibration exposed subjects was less than $5 \%$ in all sensory areas. The results of these basic clinical tests, as opposed to the more sophisticated two point discrimination, depth-sense aesthesiometry and plethysmography, are encouraging and deserve further attention in the 
assessment of VWF disability. Such sensory tests were very much part of the basic skills of the early clinicians in the Hamilton-Rothstein era.

Finally, over the 60 year interval between the 1918 and 1978 VWF surveys, no change in the design of the air hammers has taken place and the measured vibration characteristics of this tool are outside the recommended limits. ${ }^{7}$ The VWF data presented in this paper, from the 1918 HamiltonRothstein findings and the 1978 survey, call for an urgent appraisal of the design of hand held pneumatic hammers to remove one cause of Raynaud's phenomenon of occupational origin.

We express our grateful thanks to Bedford County medical officer, the Bedford Chamber of Commerce, and the Indiana Laborers' Training Institute for their valuable help and advice. The stonecutters and drillers of Bedford are especially thanked for their cooperation.

\section{References}

' Hamilton A. A study of spastic anemia in the hands of stonecutters. Washington: Government Printing Office, 1918. (Bull US Bureau of Labor Statistics No 236: Ind Accidents and Hygiene Series, No 191:53-66.)

${ }^{2}$ Rothstein T. Report of the physical findings in eight stonecutters from the limestone region of Indiana. Washington: Government Printing Office, 1918. (Bull US Bureau of Labor Statistics, No 236: Ind Accidents and Hygiene Series, No 19:6796.)

${ }^{3}$ Taylor W, Pelmear PL, eds. Vibration white finger in industry. London: Academic Press, 1975: introduction, XXI.

4 Wasserman DE, Taylor W, Behrens V, Samueloff S, Reynolds D. Vibration white finger disease in US workers using pneumatic chipping and grinding hand tools. Vol 1. Epidemiology. Cincinnati, Ohio: Department of Health and Human Services, 1982. (NIOSH publication No 82-118.)

5 Wasserman DE, Reynolds D, Behrens V, Taylor W, Samueloff $\mathrm{S}$, Basel R. Vibration white finger disease in US workers using pneumatic chipping and grinding hand tools. Vol 2. Engineering testing. Cincinnati, Ohio: Department of Health and Human Services, 1981. (NIOSH publication No 82-101.)

- International Organisation for Standardisation. Guide for the measurement and the assessment of human exposure to vibration transmitted to the hand. Geneva. ISO, 1979. (ISO/DIS/ 5349.)

7 Taylor $\mathrm{W}$, ed. The vibration syndrome. London: Academic Press, 1974: introduction, 2. 